\title{
National Security and Surveillance: Measuring the Public Impact of the GCSB Amendment Bill and the Snowden Revelations in New Zealand
}

\author{
ROBERT G. PATMAN and LAURA SOUTHGATE
}

\begin{abstract}
In New Zealand, Edward Snowden's revelations about the extraordinary scope of the National Security Agency's (NSA's) surveillance capabilities and the facilitating role of the Five Eyes alliance converged with increasing public concerns about the Government Communications Security Bureau (GCSB) Amendment and Related Legislation Bill in 2013. This generated an intense and sustained debate in the country about surveillance policy. It was a debate in which the Prime Minister John Key has featured prominently. While apparently unable to clearly refute Snowden's claims concerning mass surveillance in New Zealand, John Key's vigorous public interventions helped counter the short-term political and diplomatic fallout. However, the longterm impact of public concerns over the surveillance policies of the Key government may be much harder to predict in what is an intimate democracy, and the prospect of substantial political blowback cannot be ruled out.
\end{abstract}

The Snowden revelations has coincided with growing public disquiet in New Zealand about the role of the Government Communications Security Bureau (GCSB), an agency responsible for foreign signals intelligence collection and counter-intelligence operations. This disquiet had notably increased in May 2013 after the John Key government announced it would introduce the GCSB Amendment and Related Legislation Bill (hereafter the GCSB Amendment Bill), a measure which proposed to significantly extend the powers of the GCSB to collect information on New Zealanders for the use of other government departments including the New Zealand Police, New Zealand Defence Force (NZDF) and the New Zealand Special Intelligence Service (NZSIS).

This article seeks to evaluate, in a systematic fashion, the public impact of the Snowden revelations on national security and surveillance policy in New Zealand. In 
the first part of the article, we consider New Zealand's intelligence community, its international connections and describe how two developments - the GCSB Amendment Bill and the Snowden leaks - have caused public consternation over surveillance policy in New Zealand. In the second section, a conceptual model developed by Michelle Hale Williams is outlined to help define, understand and measure the impact factor in public life. In the third section of the essay, we utilize the Williams' framework, in a bottom up fashion, to examine the impact of Snowden on public and political debate in New Zealand, including the role of the media.

The fourth part of the article looks at the effect of Snowden's leaks on the institutional environment within New Zealand. The fifth section explores the impact of Snowden's revelations on New Zealand government's policy-making during this period. The sixth and final section provides an overall assessment and concludes that in the short-term, at least, the substantial impact of the Snowden revelations on public debate in New Zealand did not translate into significant changes to government policy in the national security area. However, it is argued that the long-term prognosis for government policy in contested, complex areas like surveillance policy in an intimate democracy like New Zealand may well prove to be quite different.

\section{National Security and the New Zealand Intelligence Community}

The post 9/11 - era has witnessed a significant expansion of American resources devoted to intelligence gathering. However, the extent of this trend was not fully apparent until a former NSA contractor, Edward Snowden, surfaced in Hong Kong in May 2013 with thousands of highly classified intelligence documents in his possession. Starting on 5 June 2013, Mr Snowden began to leak documents to the 
public through selected media outlets and has continued to do so ever since. According to Daniel Ellsberg, 'there has not been in American history a more important leak than Edward Snowden's release of NSA material-and that definitely includes the Pentagon Papers 40 years ago'. ${ }^{1}$ Through the release of classified documents, it was revealed that the NSA has gathered two types of information metadata, which can be defined as the footprint of electronic device use, ${ }^{2}$ and content data. Signals intercept programs like PRISM and X-KEYSCORE have radically improved the surveillance capabilities of the NSA and enabled the United States (US) government to collect personal data on a massive scale. ${ }^{3}$

Snowden's disclosures have had ramifications for New Zealand. Compared to many Western countries, New Zealand has a relatively small and centralized intelligence community. ${ }^{4}$ Key agencies include the NZSIS, the GCSB and the National Assessments Bureau (NAB). ${ }^{5}$ The NZSIS is responsible for advising the government on matters relating to New Zealand's national security interests. While the NZSIS focuses mainly on domestic security intelligence, it also has a role in collecting foreign intelligence. The NZSIS budget for 2012-13 was around NZ\$37.5 million. ${ }^{6}$ The GCSB has a dual function in foreign signals intelligence collection and counter-intelligence operations. This agency has two communication interception

\footnotetext{
${ }^{1}$ Daniel Ellsberg, 'Edward Snowden: saving us from the United Stasi of America', The Guardian, 10 June 2013, http://www.theguardian.com/commentisfree/2013/jun/10/edward-snowden-united-stasiamerica (accessed 01 November 2014).

${ }^{2}$ Ben Grubb and James Massola, 'What is 'metadata' and should you worry if yours is stored by law?' The Sydney Morning Herald, 6 August 2014, http://www.smh.com.au/digital-life/digital-lifenews/what-is-metadata-and-should-you-worry-if-yours-is-stored-by-law-20140806-100zae.html (accessed 01 November 2014).

${ }^{3}$ Glenn Greenwald, No Place to Hide: Edward Snowden, the NSA and the Surveillance State (London: Hamish Hamilton, 2014) p.153; Paul Buchanan, 'Snowden Leaks sure to catch NZ out', The New Zealand Herald, 3 December 2013, http://www.nzherald.co.nz/world/news/article.cfm?c id=2\&objectid=11165857 (accessed 15 October 2014).

${ }^{4}$ Jim Rolfe, 'New Zealand: Small Community, Central Control' in Daniel Baldino (eds.) Democratic Oversight of Intelligence Services (Annandale: The Federation Press, 2010) p.109.

${ }^{5}$ Ibid., pp.109-110.

${ }^{6}$ New Zealand Security Intelligence Service (NZSIS), Annual Report for the Year Ended 30 June 2013

(New Zealand Government, Wellington) p.31, http://www.security.govt.nz/assets/media/annualreports/nzsis-ar13.pdf (accessed 01 November 2014).
} 
stations: the high frequency radio interception station at Tangimoana, near Palmerston North, and the satellite communications interception station at Waihopai, near Blenheim. The National Cyber Security Centre (NCSC) has been located with the GCSB since its establishment in 2011. In 2012-2013, the GCSB budget was reported to be NZ\$67.9 million. ${ }^{7}$ The NAB is responsible for collecting and interpreting information on external concerns and developments. Located in the Department of the Prime Minister and Cabinet (DPMC), NAB provides analysis and assessment, based on public and intelligence sources, to inform government decision-making, but it does not provide policy advice. NAB has a budget of approximately NZ\$3.5 million. $^{8}$

New Zealand's intelligence services are supervised and directed by the Office of the Prime Minister and the Cabinet Strategy Subcommittee on Intelligence and Security (CSSIS). Accountability and oversight of the intelligence community involves both parliamentary and official bodies in New Zealand's Westminster style political system. In 1996, the Intelligence and Security Committee of Parliament was given the task of reviewing the activities of the NZSIS and the GCSB. The fivestrong committee consists of the Prime Minister as Chair, the Leader of the Opposition, two members nominated by the Prime Minister and one member nominated by the Leader of the Opposition in consultation with all parties in Parliament. ${ }^{9}$ Some oversight is also provided by three other entities. ${ }^{10}$

\footnotetext{
${ }^{7}$ Government Communications Security Bureau (GCSB), Annual Report for the Year Ended 30 June 2013 (New Zealand Government, Wellington) p.29, http://www.gcsb.govt.nz/assets/GCSB-AnnualReports/GCSB-Annual-Report-2013.pdf (accessed 01 November 2014).

${ }^{8}$ New Zealand Intelligence Community, 'National Assessment Bureau (NAB)'

http://www.nzic.govt.nz/about-us/nab/ (accessed 01 November 2014).

${ }^{9}$ Rolfe, 'New Zealand: Small Community, Central Control', pp.113-114.

${ }^{10}$ First, the Commissioner of Security Warrants is an office established in 1999. Appointed by the Governor-General on the recommendation of the Prime Minister, the Commissioner's role is to advise the Prime Minister (the Minister in charge of the NZSIS and GCSB) on domestic interception warrants and to issue them jointly with the Prime Minister. Second, the Inspector-General of Intelligence and Security (IGIS) is responsible for reviewing any matter relating to the NZSIS or GCSB where New
} 
The publication of leaked documents by Snowden has shone the spotlight on a little known global surveillance apparatus known as 'Five Eyes' run by the United States' NSA in close cooperation with partner intelligence agencies in Australia, Canada, United Kingdom (UK) and New Zealand. ${ }^{11}$ In particular, the Snowden revelations have highlighted the close links and coordination between the GCSB and the NSA organization. Historically, cooperation in signals intelligence between the Five Eyes countries officially began in the early stages of the Cold War, prompted by the perceived threat of the Soviet Union. The Five Eyes states developed what was called ECHELON, a surveillance network to monitor the military and diplomatic communications of the Soviet Union and its Eastern bloc allies. ${ }^{12}$

By the end of the $20^{\text {th }}$ century, following the demise of the Cold War and deepening globalization, the ECHELON surveillance network had evolved into a global system capable of intercepting massive amounts of private communications, including telephone calls, fax, email and other data traffic. ${ }^{13}$ The NSA designed the ECHELON system to interconnect the process of collecting information within the

Zealand citizens have been or may have adversely affected or New Zealand laws contravened. Established in 1996, the IGIS is appointed by the Governor-General on the recommendation of the Prime Minister. The IGIS is required to have previously held office as a judge of the High Court of New Zealand. Third, the Office of the Privacy Commissioner is statutorily independent and holds an oversight function in relation to the intelligence community. Amongst other things, the Commissioner investigates complaints that personal information has been accessed or treated by intelligence agencies (most generally the NZSIS) in ways that were not consistent with the 1993 Privacy Act. See Rolfe, 'New Zealand: Small Community, Central Control', pp.114-115.

${ }^{11}$ Glenn Greenwald and Ewen MacAskill, 'Boundless Informant: the NSA's secret tool to track global surveillance data', The Guardian, 8 June 2013, http://www.theguardian.com/world/2013/jun/08/nsaboundless-informant-global-datamining (accessed 03 November 2014).

12 'What you need to know about Echelon', BBC News, 29 May 2001, http://news.bbc.co.uk/2/hi/sci/tech/1357513.stm (accessed 03 November 2014).

${ }^{13}$ Gerhard Schmid, 'Report on the existence of a global system for the interception of private and commercial communications (ECHELON interception system) 2001/2098(INI)', European Parliament Session Document, 11 July 2001, http://www.europarl.europa.eu/sides/getDoc.do?pubRef=//EP//TEXT+REPORT+A5-2001-0264+0+DOC+XML+V0//EN (accessed 14 May 2015). 
Five Eyes alliance. ${ }^{14}$ This means, for example, that considerable amounts of the intelligence collected by the GCSB is not screened in New Zealand, but sent directly to the headquarters of the agency concerned. ${ }^{15}$ Consequently, the GCSB, the Government Communications Headquarters (GCHQ) in the UK, the Communications Security Establishment Canada (CSEC), and the Australian Signals Directorate (ASD) are component parts of what is an integrated NSA led - international intelligence operation. $^{16}$

Thus, New Zealand has had a long history of participating in the Five Eyes alliance. Successive elected governments in Wellington have continued to support New Zealand's participation in this arrangement. Presumably, New Zealand governments have believed they gain far more information on which to base their own decisions than would otherwise be available. New Zealand's involvement in the Five Eyes alliance did not prevent the adoption of a non-nuclear security policy in the mid1980s. At the same time, New Zealand felt free to oppose the US-led invasion of Iraq in 2003. Rather than eroding New Zealand's sovereignty, participation in the Five Eyes partnership has been seen by decision-makers as enhancing the country's capacity to conduct an independent foreign policy.

The Course of Events: The GCSB Amendment Bill and the Snowden Leaks

A triggering event for public concerns about surveillance policy in New Zealand was the arrest of Mr Kim Dotcom, founder of the 'Mega Upload' file-sharing website, and three business associates on 20 January 2012. Dotcom's arrest occurred during a

\footnotetext{
${ }^{14}$ Nicky Hager, 'Exposing the Global Surveillance System', Covert Action Quarterly (Winter 1996/1997).

${ }^{15}$ Ibid.

${ }^{16}$ Ibid.
} 
high-profile armed raid on his home, which involved 76 officers and two helicopters. ${ }^{17}$ Two weeks earlier, on 5 January 2012, indictments were filed in Virginia, USA, against Dotcom and some other 'Mega Upload' executives involving alleged crimes relating to online piracy, including racketeering, conspiring to commit copyright infringement, and conspiring to commit money laundering. ${ }^{18}$ The raid on Dotcom's home involved the New Zealand Police and the United States Federal Bureau of Investigation (FBI).

In the legal case that followed, it was revealed that 'warrants used in the raid were illegal because they were used to seize material that was irrelevant to the investigation, that the FBI had illegally copied the contents of computer hard drives seized in the raid, and that the GCSB had unlawfully spied on Dotcom prior to the raid, supplying information to the police relating to his movements and personal communications'. ${ }^{19}$ Since Dotcom was granted New Zealand residency in 2010, he was legally entitled to protection from GCSB surveillance under the terms of the GCSB Act's statutory framework. As a consequence of the GCSB's illegal spying activity, New Zealand Prime Minister John Key commissioned Cabinet Secretary Rebecca Kitteridge to carry out a review of compliance systems and processes at the GCSB in March $2013,{ }^{20}$ which culminated in the release of the Kitteridge Report. The report found that there were 'underlying problems within GCSB, concerning

\footnotetext{
17 'Editorial: Kim Dotcom sets off year of fireworks for politicians', The New Zealand Herald, 27 December 2012, http://www.nzherald.co.nz/opinion/news/article.cfm?c_id=466\&objectid=10856144 (accessed 03 November 2014).

${ }_{18}$ The United States Department of Justice, 'Justice Department Charges Leaders of Megaupload with Widespread Online Copyright Infringement', Office of Public Affairs, 19 January 2012,

http://www.justice.gov/opa/pr/justice-department-charges-leaders-megaupload-widespread-onlinecopyright-infringement (accessed 03 November 2014).

19 Joe Burton, 'Small States and Cyber Security: The Case of New Zealand', Political Science 65/2 (2013) p.232.

${ }^{20}$ John Roughan, John Key: Portrait of a Prime Minister (London: Penguin, 2014).
} 
GCSB's structure, management of its information, capability and capacity'. ${ }^{21}$ The report revealed 55 cases of unlawful GCSB surveillance over nine years, involving 88 New Zealand residents and permanent residents. ${ }^{22}$ The report also recommended that external oversight of the GCSB be strengthened. ${ }^{23}$

Prime Minister John Key acknowledged 'this review will knock public confidence in the GCSB', but he said one of the central findings of the Kitteridge Report concerned the inadequacy of the GCSB Act 2003. Mr Key stated 'the act governing the GCSB is not fit for purpose and probably never has been'. ${ }^{24}$ As a response to the Kitteridge Report, John Key announced on 8 May 2013 the GCSB Amendment Bill, which would extend the powers of the GCSB to collect information on New Zealanders for the use of other government departments including the New Zealand Police, NZDF and the NZSIS. ${ }^{25}$ According to this Bill, the GCSB would have three main functions. First, the GCSB would continue to collect foreign intelligence, but under the new legislation it could conduct surveillance on New Zealand citizens or permanent residents in prescribed circumstances with a warrant. ${ }^{26}$ Second, it would give the GCSB a legal mandate to assist the police, the NZDF and NZSIS with their work and therefore expanded the operational range of the organization. Third, the legislation would extend the GCSB's cyber-security role to include protecting private-sector cyber systems,${ }^{27}$ a development that had the potential

\footnotetext{
${ }^{21}$ Rebecca Kitteridge, 'Review of Compliance at the Government Communications Security Bureau', March 2013, http://www.gcsb.govt.nz/assets/GCSB-Compliance-Review/Review-of-Compliance.pdf (accessed 07 October 2014) p.6.

${ }^{22}$ Ibid., p. 18.

${ }^{23}$ Ibid., p.6.

${ }^{24}$ Imogen Crispe and Thomas Mead, 'The GCSB Report: an in depth look', 3 News, 9 April 2013, http://www.3news.co.nz/politics/the-gcsb-report-an-in-depth-look-2013040918 (15 November 2014)

${ }^{25}$ New Zealand Parliament, 'Government Communications Security Bureau and Related Legislation Amendment Bill', 20 August 2013, http://www.parliament.nz/en-

nz/pb/legislation/bills/00DBHOH_BILL12122_1/government-communications-security-bureau-andrelated-legislation (accessed 27 November 2014).

${ }^{26}$ Valerie Redmond, 'I spy with my not so little eye: A comparison of surveillance law in the United States and New Zealand', Fordham International Law Review 37/3 (2014) p.759.

${ }_{27}$ Audrey Young, 'GCSB bill passes after final reading', The New Zealand Herald, 21 August 2013,
} 
to significantly increase the government's ability to monitor the Internet in relation to New Zealand. At the same time, the GCSB under the changes was still able to provide and receive information from other intelligence agencies within ECHELON. ${ }^{28}$ This arrangement created a potential loophole in surveillance law whereby the New Zealand government could circumvent its own laws by sharing information on its own citizens with other countries. $^{29}$

Shortly after the release of the Kitteridge Report, Edward Snowden began to release a series of highly classified intelligence documents relating to global surveillance. The steady and cumulative impact of the continuing Snowden revelations has intensified public concerns in New Zealand about spying. Amongst other things, Snowden, his close collaborator, Glen Greenwald, an American journalist and Nicky Hager, a New Zealand journalist, have alleged the GCSB directly supplies the NSA with data derived from 'full-take' surveillance of 'a surprising array of New Zealand's friends, trading partners and close Pacific neighbors' ${ }^{30}$; that New Zealand had been spying on democracies for economic advantage, such as the Brazilian energy company PetroBras ${ }^{31}$ and had used the GCSB in a unsuccessful bid to help New Zealand Trade Minister, Tim Groser, become Director of the World Trade Organization (WTO) in $2013^{32}$; and that the GCSB has been involved in the domestic mass surveillance of New Zealanders. According to Snowden, the GCSB 'is

http://www.nzherald.co.nz/nz/news/article.cfm?c id=1\&objectid=11112152 (accessed 27 October 2014).

${ }^{28}$ Redmond, 'I spy with my not so little eye,' p.768.

${ }^{29}$ Ibid., p.769.

${ }^{30}$ Nicky Hager and Ryan Gallagher, 'Snowden Revelations/The Price of the Five Eyes Club: Mass spying on friendly nations', The New Zealand Herald, 05 March 2015, http://www.nzherald.co.nz/nz/news/article.cfm?c_id=1\&objectid=11411759 (accessed 15 March 2015).

${ }^{31}$ Michael Botur, 'The GCSB does not conduct mass surveillance on Kiwis - Key', The New Zealand Herald, 14 September 2014,

http://www.nzherald.co.nz/nz/news/article.cfm?c_id=1\&objectid=11324452 (accessed 27 October 2014).

32 Tova O'Brien, 'GCSB claims detract from South Korea free trade deal', 3 News, 23 March 2015, http://www.3news.co.nz/nznews/gcsb-claims-overshadow-south-korean-free-trade-deal-2015032322 (accessed 25 March 2015). 
directly involved in the untargeted, bulk interception and algorithmic analysis of private communications sent via internet, satellite, radio, and phone networks' ${ }^{33}$

While the Key government vehemently denied such claims, Snowden countered by saying that 'any statement that mass surveillance is not performed in New Zealand, or that the internet communications are not comprehensively intercepted and monitored, or that this is not intentionally and actively abetted by the GCSB, is categorically false. If you live in New Zealand, you are being watched'. ${ }^{34}$ Furthermore, Greenwald claimed that the GCSB Amendment Act was designed to enable mass metadata collection, rather than prevent it. ${ }^{35}$ In other words, Greenwald contended the 'New Zealand's government's position privately was the exact opposite of what they were saying publicly'. ${ }^{36}$

\section{Conceptualizing Public Impact: The Williams’ Model}

For the purpose of this study, the concept of impact is broadly defined in terms of influence. ${ }^{37}$ According to this definition, influence 'is the capacity to change a course of events that might develop differently without the introduction of the impact stimulus...influence determines the ability to alter political discourse, to introduce important issues, to develop fresh ideas, and to induce action'. ${ }^{38}$ In order to help

\footnotetext{
${ }^{33}$ Edward Snowden, 'Snowden: New Zealand's Prime Minister isn't telling the truth about mass surveillance', The Intercept, 15 September 2014,

https://firstlook.org/theintercept/2014/09/15/snowden-new-zealand-surveillance/ (accessed 04 October 2014). 
measure the effects of the Snowden revelations in New Zealand, the authors draw on a model that identifies impact at three different levels: agendas, institutions and policy. ${ }^{39}$ For Williams, 'one must account for the opportunity to influence decisionmaking prior to the stage of formal legislation' ${ }^{40}$ According to this view, the 'critical stage' of influence is found in 'political debates, popular discourse, or the process of bringing an issue to saliency'. ${ }^{41}$ A pyramid model has been used to represent the different possibilities for impact (see Figure 1). The bottom level represents the widest possibilities for impact, and the second and third levels represent narrower and more concrete possibilities for impact respectively.

The agenda level emphasizes the degree of influence that events have on popular discourse, public attention, and society at large. Williams' agenda level is consistent with the works of Mark Considine, ${ }^{42}$ John Kingdon, ${ }^{43}$ Frank Baumgartner and Bryan Jones. ${ }^{44}$ From this literature, Williams derives an understanding of 'agenda' as 'the cycle of new ideas about policy replacing the old ideas'. ${ }^{45}$ Williams draws on the work of Considine, who believes that 'one of the most important aspects of policymaking in any political system is the pre-decision stage at which a potentially wide range of concerns and preferences are fashioned into some actionable list of proposals'. ${ }^{46}$ This pre-decision level includes the 'informal political discourse in a society and the way actors in the political system respond'. ${ }^{47}$ Interaction at the agendas level is a dynamic process. This is according to the work of Kingdon, where 'problems, policies, and opportunities combine and interact with the political

\footnotetext{
${ }^{39}$ Ibid., p.43-46.

${ }^{40}$ Ibid., p.43.

${ }^{41}$ Ibid.

${ }^{42}$ Mark Considine, 'Making up the Government's Mind: Agenda Setting in a Parliamentary System', Governance 11/3 (1998) pp.297-317.

${ }^{43}$ John Kingdon, Agendas, Alternatives and Public Policy (Boston: Little, Brown \& Co., 1984).

${ }^{44}$ Frank Baumgartner and Bryan Jones, Agendas and Instability in American Politics (Chicago: The University of Chicago Press, 1993).

${ }^{45}$ Williams, The Impact of Radical Right-Wing Parties, p.44.

${ }^{46}$ Considine, 'Making up the Government's Mind', p.297.

${ }^{47}$ Williams, The Impact of Radical Right-Wing Parties, p.44.
} 
environment'. ${ }^{48}$ For Williams, 'political agenda-setting incorporates a variety of actors outside of the legislature including political parties, interest groups, social movements and the priorities of the general public or voters that all combine to affect agendas'.49

The institutional level is concerned with the impact of events on the political system, or the 'institutional structure of government'. ${ }^{50}$ This is a narrower level of impact that affects the constitutional form of government, political party ideologies, party-to-party relationships, and electoral dynamics. At the institutional level, as with the agendas level, Williams believes there is a dynamic relationship, where political parties can alter the political system. ${ }^{51}$ According to this view, political structures can change in response to the impact of an event stimulus. This is because electoral politics 'presents a zero-sum dilemma', where votes are largely obtained at the expense of other parties. ${ }^{52}$ An impact stimulus may force parties to shift along the ideological spectrum, or to expand into new areas in order to appeal to voter's demands. In rare cases, 'electoral system rules may change or constitutions may be revised' ${ }^{53}$

\footnotetext{
${ }^{48}$ Ibid., p.44.

${ }^{49}$ Ibid., p.44.

${ }^{50}$ Ibid., p.45.

${ }^{51}$ Ibid., p.45.

${ }^{52}$ Ibid., p.45.

${ }^{53}$ Ibid., p.45.
} 


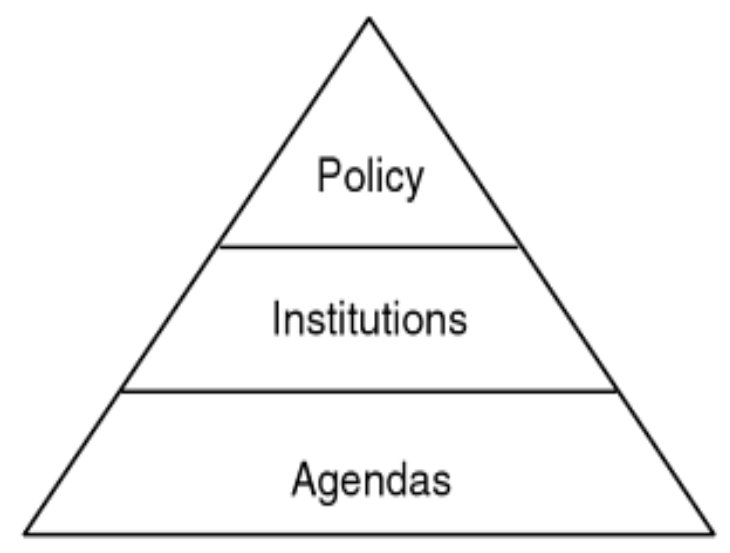

Figure 1 Levels of Impact

In the top-tier of Williams' pyramid, the policy-making level of impact is evident. Here the formulation and implementation of legislation could be seen as a 'concrete' indicator of impact. This level represents the most visible expression of influence because legislative activities are relatively easy to document. ${ }^{54}$ However, the policy level also represents 'the most difficult causal leap'. ${ }^{55}$ This is because 'any issue has multiple influences upon its legislative form and outcome'. ${ }^{56}$

\section{Impact of the Surveillance Controversy at the Agendas level}

According to the social agendas level of the Williams' model, an impact stimulus can affect public opinion, political discourse and the role of the media. Within New Zealand, a spirited debate on surveillance emerged after proposed changes to the GCSB Act in 2013.

\footnotetext{
${ }^{54}$ Ibid., p.46.

${ }^{55}$ Ibid., p.46.

${ }^{56}$ Ibid., p.46.
} 
The Amendment Bill was said to be a response to a review of compliance systems and processes at the GCSB. Arguing that the 2003 Act governing the GCSB was inadequate, Prime Minister Key announced his intention to introduce an Amendment Bill, which would extend the powers of the GCSB to collect information on New Zealanders.

In Parliament, the Bill encountered fierce opposition. Grant Robertson, the then Deputy Labour Leader, observed:

New Zealanders have lost their faith in the intelligence and security agencies of this country, and I believe that that is a direct result of the way that the Prime Minister has undertaken his duties as the person whom we as New Zealanders have, on our behalf, in charge of those agencies. He has got that oversight and he is not performing properly. New Zealanders are worried about their privacy, they are worried about whether their details are available to Governments overseas, and this Government wants to ram legislation through this committee in a way that I do not believe many New Zealanders would accept. We need better oversight of our intelligence agencies. ${ }^{57}$

Phil Goff, former Labour Leader, did not believe that the GCSB Amendment Bill addressed the shortcomings identified in the GCSB review and said a Labour-led government would conduct an inquiry into New Zealand's intelligence services:

We needed an inquiry because this legislation and its associated bill came about because of abuse of power by the GCSB. They came about because there are not sufficient safeguards on how the GCSB exercises its authority. In our fraternal parliaments in Australia, Canada, and the United Kingdom, they do not put the Minister in charge of the agency on the committee that oversees that. They keep Ministers off. But we have our Prime Minister chairing the Intelligence and Security Committee, setting the agenda, and very rarely calling it together and we call that a safeguard against the abuse of powers of the GCSB. ${ }^{58}$

${ }^{57}$ New Zealand Parliament Hansard Debates, 'Intelligence and Security Committee - Membership', 13 June 2013, Volume 691, p.11134, http://www.parliament.nz/ennz/pb/debates/debates/50HansD_20130613_00000020/intelligence-and-security-committee\%E2\%80\%94-membership (accessed 10 December 2014).

${ }^{58}$ Ibid. 
However, John Key, the Prime Minister and the Minister responsible for the GCSB and NZSIS, insisted that the 2013 GCSB Bill was not 'a revolution in the way New Zealand conducts its intelligence operations' and said if he could disclose some of the briefings he had received about security risks to New Zealand, it would 'cut dead $^{59}$ some of the opposition to the legislation:

I have access to evidence that shows that without the Government Communications Security Bureau (GCSB) and the SIS, our national security would be vulnerable. There are threats our Government needs to protect New Zealanders from. Those threats are real and ever-present and we underestimate them at our peril. ${ }^{60}$

Mr Key added that others 'may play politics with the security and lives of New Zealanders, but I cannot and I do not and I will not'.61 The Prime Minister maintained the new legislation would 'put in place a stronger oversight regime that will go some way to rebuilding public confidence in the GCSB ${ }^{62}$ He also claimed that the GCSB Amendment Bill 'actually tightens, not widens, the existing regime'. ${ }^{63}$ The GCSB Amendment Bill was passed into law at its third reading by a vote of 61 to 59, a margin of just two votes.

Outside Parliament, the GCSB Amendment Bill was the subject of major public concern. It was widely feared that the legislation effectively allowed the GCSB to engage in wholesale spying on New Zealanders. ${ }^{64}$ One opinion poll taken after the

\footnotetext{
${ }^{59}$ Audrey Young, 'GCSB bill passes after final reading', The New Zealand Herald, 21 August 2013, http://www.nzherald.co.nz/nz/news/article.cfm?c_id=1\&objectid=11112152 (accessed 27 October 2014).

${ }^{60}$ New Zealand Parliament Hansard Debates, 'Government Communications Security Bureau

Amendment Bill, Inspector-General of Intelligence and Security Amendment Bill, Intelligence and Security Committee Amendment Bill — Third Readings', Sitting date 21 August 2013, volume 692, http://www.parliament.nz/en-nz/pb/debates/debates/50hansd 20130821 00000020/governmentcommunications-security-bureau-amendment-bill (accessed 10 December 2014).

${ }^{61}$ John Key cited in Young, 'GCSB bill passes after final reading'.

${ }^{62}$ Anna Crowe, 'EU Parliament slams New Zealand for being part of NSA mass surveillance', Privacy International, 15 February 2014, http://nzhumanrightsblog.com/newzealand/influential-europeanparliament-committee-slams-new-zealand-for-being-part-of-nsa-mass-surveillance/ (accessed 15 September 2014).

${ }_{63}$ Young, "GCSB bill passes after final reading'.

64 'New Zealand passes bill allowing domestic spying', ABC News, 22 August 2013, http://www.worldaffairsjournal.org/content/new-zealand-passes-bill-allowing-domestic-spying (accessed 04 December 2014).
} 
passing of the legislation found 75 per cent of respondents were concerned about the changes. ${ }^{65}$ Another opinion poll conducted by TV3, and cited by Labour MP Phil Goff in Parliament, found that 40 per cent of New Zealanders did not have trust and confidence in the GCSB. ${ }^{66}$ Shortly before the passage of the legislation, opponents of the GCSB Amendment Bill on 27 July 2013 staged nationwide protests in eleven major towns and cities. ${ }^{67}$ There were also a substantial number of critical as well as supportive media editorials on the GCSB legislation. ${ }^{68}$

Amongst other things, the media highlighted the issue of the GCSB's access to 'metadata', which includes the duration and time of calls between numbers, sender and recipient of emails, time of emails and the location of information. ${ }^{69}$ Protection under the GCSB Amendment Act is only extended to private communications and does not extend to metadata or to conversations that could 'reasonably' be expected to be intercepted. ${ }^{70}$ This is despite the fact that metadata encompasses personal information and can build a more detailed profile than listening in to actual content. ${ }^{71}$ Concerns have also been raised regarding the term 'private communication' in the GCSB Amendment Act. Under the Act, a communication can only be 'private', and therefore protected from interception, if one of the parties has a 'reasonable

65 'New Zealand passes bill allowing domestic spying'.

${ }^{66}$ New Zealand Parliament Hansard Debates, 'Intelligence and Security Committee'.

${ }^{67}$ Rob Kidd and Francesca Lee, 'Thousands join rally against GCSB', The Dominion Post, 27 July 2013, http://www.stuff.co.nz/dominion-post/news/politics/8972321/Thousands-join-rally-againstGCSB (accessed 04 October 2014).

68 'Editorial: Spy bill needs more checks and balances', The Dominion Post, 27 July 2013, http://www.stuff.co.nz/dominion-post/comment/editorials/8969381/Editorial-Spy-bill-needs-morechecks-and-balances (accessed 04 October 2014). See also Bryce Edwards, 'Political Round-up: A marvellous GCSB debate', The New Zealand Herald, 19 August 2013,

http://www.nzherald.co.nz/nz/news/article.cfm?c id=1\&objectid=11110908 (accessed 04 October 2014).

${ }^{69}$ Glenn Greenwald and Spencer Ackerman, 'NSA collected US email records in bulk for more than two years under Obama', The Guardian, 27 June 2013 ,

http://www.theguardian.com/world/2013/jun/27/nsa-data-mining-authorised-obama (accessed 04 October 2014).

${ }^{70}$ Andrea Vance, 'Demystifying the GCSB bill: Spies and Lies', Stuff News, 20 August 2013, http://www.stuff.co.nz/national/politics/9064984/Demystifying-the-GCSB-bill-Spies-and-lies (27 September 2014).

${ }^{71}$ Ewen Macaskill and Gabriel Dance, 'The NSA Files: Decoded', The Guardian, 01 November 2013, http://www.theguardian.com/world/interactive/2013/nov/01/snowden-nsa-files-surveillancerevelations-decoded\#section/1 (accessed 27 September 2014). 
expectation' that their communication will not be intercepted. ${ }^{72}$ A 'reasonable expectation' in this context is not about privacy in the wider meaning of the term or loss of privacy. ${ }^{73}$ Defining the term in the GCSB Amendment Act requires a much narrower and focused enquiry as to whether the communication will be intercepted. It is irrelevant whether the interception occurs overseas or within New Zealand. ${ }^{74}$ As such, some commentators argue that warrantless surveillance of New Zealanders by the GCSB is entirely possible. ${ }^{75}$

Public Debate on Surveillance: Phase Two

The timing of the Snowden revelations, coming one month after proposed changes to the GCSB Act, deepened the debate concerning the surveillance capabilities of the New Zealand intelligence service. David Shearer, the then Leader of the Labour opposition party, said the Key Government had missed a major political opportunity to make effective changes to the intelligence community:

The revelations of Bradley Manning and Edward Snowden have created global disquiet... We could have seized the chance to thoroughly investigate how our intelligence sector works in an increasingly global environment. ${ }^{76}$

Dr Russel Norman, the Co-Leader of the opposition Green Party, raised questions about the national accountability of the GCSB:

What we discovered from the Snowden revelations is that the GCSB, which is presumably the agency, is providing vast amounts of data to the National Security Agency. In the information that has been revealed by Snowden, we now know that New Zealand is one of the sources of all the data that is provided to the National Security Agency about internet traffic, phone traffic,

\footnotetext{
72 Dennis Tegg, 'Is warrant-less spying on New Zealanders lawful?' Scoop Independent News, 22 August 2014, http://www.scoop.co.nz/stories/HL1408/S00144/is-warrant-less-spying-on-newzealanders-lawful.htm (accessed 04 October 2014).

${ }^{73}$ Ibid.

${ }^{74}$ Ibid.

75 Ibid.

${ }^{76}$ New Zealand Parliament Hansard Debates, 'Government Communications Security Bureau Amendment Bill'.
} 
and all the rest of it, and presumably the GCSB is providing that information, which largely comes out of Waihopai, to that agency. ${ }^{77}$

Several academics entered the national discussion on surveillance. According to Kevin Clements, the question facing all New Zealanders after the Snowden revelations is 'Who guards the guards?' In his view, the global war on terror had dramatically expanded state power while simultaneously eroding individual liberties and it was appropriate, therefore, that New Zealand should now 'have a Commission of inquiry to re-evaluate the value of the Five Eyes security arrangement and ask whether New Zealand's foreign policy is enhanced or diminished by it'. ${ }^{78}$ The impact of Snowden's revelations on individual civil liberties was also a source of concern to Greg Dawes in at least two ways. First, while the NSA only claims to be collecting data on non-Americans, that 'includes most of us, since almost all our online data at some point passes through servers in the United States'. ${ }^{79}$ Second, the British GCHQ 'has already been receiving information from the American spy programme. So it is likely our government has been doing the same'. ${ }^{80}$

Newspaper editorials in New Zealand responded in a largely critical fashion to the ramifications of the Snowden leaks. The Dominion Post observed:

Serious questions remain and Key has failed to answer them. Snowden is not a traitor, as former Government Communications Security Bureau head Bruce Ferguson claims. In fact, he is a hero of democracy, who, at his own peril, revealed a staggering worldwide bugging machine that clearly threatens our liberties. ${ }^{81}$

\footnotetext{
77 New Zealand Parliament Hansard Debates, 'Volume 692, Week 50 - Tuesday, 6 August 2013', Sitting date: 06 August 2013, Volume: 692, http://www.parliament.nz/ennz/pb/debates/debates/daily/50HansD_20130806/volume-692-week-50-tuesday-6-august-2013 (accessed 10 December 2014).

${ }^{78}$ Kevin P. Clements, 'Safety possible without surveillance', Otago Daily Times, 5 June 2014, http://www.odt.co.nz/opinion/opinion/304782/safety-possible-without-surveillance (accessed 10 December 2014).

${ }^{79}$ Greg Dawes, 'Time to show the door to any spies inside', Otago Daily Times, 12 June 2013, http://www.odt.co.nz/opinion/opinion/260625/time-show-door-any-spies-inside (accessed 10 December 2014).

${ }^{80}$ Dawes, 'Time to show the door to any spies inside'.

81 'Editorial: Cautious voters should assume the worst', The Dominion Post, 17 September 2013, http://www.stuff.co.nz/dominion-post/comment/editorials/10506513/Editorial-Cautious-voters-shouldassume-the-worst (accessed 10 December 2014).
} 
An editorial in the Otago Daily Times struck an equally robust line:

New Zealanders need to be reassured they are not being monitored, except in the extreme cases where terrorist activity is suspected. Casual monitoring of citizens in the hope of uncovering something of interest is reprehensible. ${ }^{82}$

Meanwhile, an editorial in the Waikato Times had this to say about the meaning of the

Snowden revelations:

The public airing of details about Prism, a massive internet surveillance programme secretly operated by the United States Government, is in a different league...The NSA doubtless believes it does nothing wrong, either, when it covertly collects information on tens of millions of US citizens from their phone calls and emails and by tapping into Google, Facebook, Microsoft, and Apple...But evidence is mounting that the war on terrorism has become a pretext for the insidious broadening of government prying. ${ }^{83}$

Despite such criticisms, Prime Minister Key said he had no concerns about Snowden's revelations and that they would not challenge 'the integrity of GCSB'. ${ }^{84}$ He justified changes to the 2003 legislation by saying that some people in New Zealand were being trained by the $\mathrm{Al}$ Qaeda terrorist organization in such places as the Yemen. ${ }^{85}$ The reality, Key noted, is that 'we [New Zealanders] live in a global environment where there are real threats' ${ }^{86}$ And he contended it would be wrong to believe there are no New Zealanders with links to terrorist organizations. ${ }^{87} \mathrm{Jim}$ Veitch, an intelligence specialist, publicly supported the Prime Minister's claim and

82 'Casual monitoring reprehensible', Otago Daily Times, 28 October 2013,

http://www.odt.co.nz/opinion/editorial/278770/casual-monitoring-reprehensible (accessed 10

December 2014).

83 'Editorial: Time to query state prying', Waikato Times, 12 June 2013,

http://www.stuff.co.nz/waikato-times/opinion/editorials/8784077/Editorial-Time-to-query-state-prying (accessed 10 December 2014).

84 'NSA tells NZ spies: 'Sniff it all'” Stuff News, 15 May 2014,

http://www.stuff.co.nz/national/politics/10046942/NSA-tells-NZ-spies-Sniff-it-all (accessed 10 December 2014).

${ }^{85}$ Rebecca Quilliam and Claire Trevett, 'PM justifies spy bill: Kiwis trained by al-Qaeda', The New Zealand Herald, 01 August 2013, http://www.nzherald.co.nz/nz/news/article.cfm?c_id=1\&objectid=10906592 (accessed 10 December 2014).

${ }^{86}$ John Key cited in Quilliam and Trevett, 'PM justifies spy bill'.

${ }^{87}$ Laura Heathcote and Felix Marwick, 'Spy laws needed because of al-Qaeda - PM', Farming Show, 01 August 2013, http://www.farmingshow.com/news/nbpol/1729548009-spy-laws-needed-because-ofal-qaeda---pm (accessed 10 December 2014). 
described the GCSB Amendment legislation as a logical response to radical changes in surveillance technology, claiming it was no longer possible to 'distinguish between internal and external intelligence in the way that once was possible'. ${ }^{88}$ While the occasional newspaper editorial also supported the security justification for expanding GCSB,${ }^{89}$ much of the media debate that took place over surveillance in New Zealand after Snowden seemed to be dominated by expressions of concern or opposition.

However, Prime Minister Key insisted 'most New Zealanders' understood and accepted his government's position on the GCSB Amendment Bill. He condemned the vocal opposition to the legislation as coming from 'experts who are not experts and really do not know what they are talking about'. ${ }^{90}$ Prime Minister Key was reported as describing the strong opposition of the New Zealand Law Society to the GCSB legislation as completely wrong. ${ }^{91}$ In a submission on the proposed Bill, the Law Society argued: 'It seems that the underlying objective of the legislation is to give the GCSB powers it previously lacked: the power to conduct surveillance on New Zealand citizens and residents'. ${ }^{92}$ The InternetNZ party also raised serious concerns about the GCSB Amendment bill claiming that its enhanced powers were too broad. In its submission, InternetNZ said it supported the provisions of the Bill that addressed cyber security of New Zealand's information infrastructure but

\footnotetext{
${ }^{88}$ Audrey Young, 'Academic up against heavies on GCSB bill', The New Zealand Herald, 06 July 2013, http://www.nzherald.co.nz/opinion/news/article.cfm?c id=466\&objectid=10895052 (accessed 10 December 2014).

${ }^{89}$ Scott Inglis, 'Editorial: Security must take priority over concerns about privacy', Bay of Plenty

Times, 27 September 2014, http://www.nzherald.co.nz/bay-of-plentytimes/news/article.cfm?c id=1503343\&objectid=1133259 (accessed 10 December 2014).

90 'An Expert who supports the GCSB Bill', Campell Live 3 News, 13 August 2013, http://www.3news.co.nz/tvshows/campbelllive/an-expert-who-supports-the-gcsb-bill2013081319\#ixzz3He9lnMbT (accessed 04 October 2014).

${ }^{91}$ Bill Bennett, 'GCSB bill too important to rush', NetHui 2013, 10 July 2013, http://2013.nethui.org.nz/2013/07/nethui-2013-gcsb-bill-too-important-to-rush (accessed 04 October 2014).

${ }_{92}$ New Zealand Law Society cited in Audrey Young, 'Law Society slams spy agency bill', The New Zealand Herald, 24 June 2013, http://www.nzherald.co.nz/nz/news/article.cfm?c_id=1\&objectid=10892498 (accessed 04 October 2014).
} 
questioned whether such a function should be located within an intelligence agency. ${ }^{93}$ But such concerns seemed to be given little serious consideration by the New Zealand government.

In a much quoted comment at a National Party press conference on 10 August 2013, Mr Key bluntly told journalist Rebecca Wright that New Zealanders care more about snapper quotas (for fishing) than the GCSB bill. ${ }^{94}$ In a subsequent interview, Prime Minister Key expanded on his assessment of public opinion in New Zealand by noting the government had received ' 124 submissions on the GCSB Bill and 30,000 on snapper [fishing quotas]'. ${ }^{95}$ In other words, the New Zealand Prime Minister was saying that while the GCSB legislation and the Snowden revelations were making the headlines, those concerns were not shared by the wider public. He also contended that 'if people aren't doing something wrong, then it's very unlikely they would be falling within the [expanded] remit of the GCSB's activities'. ${ }^{96} \mathrm{He}$ added there was considerable 'confusion' over the GCSB legislation and that the new changes to the agency did not amount to 'mass surveillance' of the country. ${ }^{97}$ The Prime Minister told the New Zealand Herald newspaper that both he and the Director of GCSB would resign if the intelligence agency was subsequently found to have conducted mass surveillance. $^{98}$

\footnotetext{
${ }^{93}$ InternetNZ cited in Young, 'Law Society slams spy agency bill'.

${ }^{94}$ John Key cited in 'An Expert who supports the GCSB Bill'.

${ }^{95}$ Karol, 'Key vs Campbell: the transcript', The Standard, 15 August 2013, http://thestandard.org.nz/key-vs-campbell-the-transcript/ (accessed 04 October 2014).

96 John Key cited in Audrey Young, 'Spy bill: 'This isn't playtime'- Key', The New Zealand Herald, 25 June 2013, http://www.nzherald.co.nz/nz/news/article.cfm?c id=1\&objectid=10892844 (accessed 04 October 2014).

${ }^{97}$ John Key cited in 'An Expert who supports the GCSB Bill'.

98 John Key's pledge cited in Audrey Young, 'Key: I'll resign if GCSB conducts mass surveillance', The New Zealand Herald, 20 August 2013, http://www.nzherald.co.nz/nz/news/article.cfm?c_id=1\&objectid=11111384 (accessed 04 October 2014).
} 


\section{Impact of the Surveillance Controversy at the Institutional Level}

According to the institutional level of Williams' impact model, developments such as the GCSB Amendment Bill and the Snowden leaks can shape the political system, political party relationships and political party structures. Certainly, with a New Zealand general election in the offing in September 2014, certain political parties sought to react to signs of public disquiet over the surveillance issue.

Kim Dotcom and 'The Moment of Truth'

In March 2014, Kim Dotcom founded the Internet Party, a New Zealand political party which pledged to stop mass surveillance of New Zealanders by the government. ${ }^{99}$ Kim Dotcom rose to prominence in New Zealand following his unauthorized surveillance by the GCSB prior to 2013. One week prior to New Zealand's general election, Dotcom's Internet Party organized what it called 'The Moment of Truth', a live event to take place in Auckland's Town Hall on 15 September. According to Dotcom, New Zealanders should 'consider the fact that the nation has quietly morphed, under the leadership of Prime Minister John Key, into the political equivalent of an American slave, responding more readily to the interests that motivate the United States than to the concerns of the Kiwis'. ${ }^{100}$ In front of a packed audience, 'The Moment of Truth' included presentations by Laila Harré, leader of the Internet Party, lawyer Robert Amsterdam, Kim Dotcom, journalist Glenn Greenwald, Edward Snowden and Julian Assange, founder of Wikileaks, by live uplink. The

\footnotetext{
${ }^{99}$ Laura Walters, 'Launch day for Kim Dotcom's Internet Party,' Stuff News, 27 March 2014, http://www.stuff.co.nz/national/politics/9873341/Launch-day-for-Kim-Dotcoms-Internet-Party (accessed 27 September 2014).

${ }^{100} \mathrm{Kim}$ Dotcom, 'Why New Zealand is a slave to US interests', CNN News, 12 September 2014, http://edition.cnn.com/2014/09/11/opinion/kim-dotcom-opinion/ (accessed 27 September 2014).
} 
event was perhaps indicative of the way 'deep investigation of government security activity may be passing from formally constituted commissions and committees toward a version of global civil society, characterized by NGOs, civil rights lawyers, journalists and regional bodies such as the Council of Europe' ${ }^{101}$

In the build-up to 'The Moment of Truth' event on 15 September 2014, a harsh war of words developed between John Key and Glenn Greenwald. The New Zealand Prime Minister quickly sought to discredit Glenn Greenwald and his stated intention to reveal evidence of domestic mass surveillance of New Zealanders by the GCSB. Mr Key repeatedly described Mr Greenwald as 'Dotcom's little henchman', ${ }^{102}$ accused Greenwald of being on Dotcom's payroll and doing 'Dotcom's bidding, ${ }^{103}$

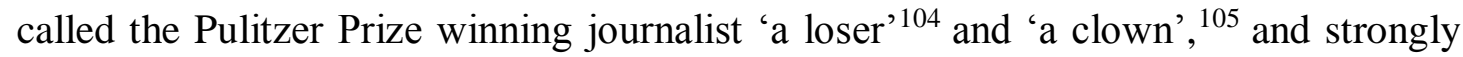
implied that Greenwald's visit to New Zealand just a week or so before the New Zealand general election was a blatant attempt to influence the outcome of the election. ${ }^{106}$ The Prime Minister added: 'There is no mass surveillance of New Zealanders by the GCSB and there never has been. Mr Dotcom's little henchman will be proven to be incorrect because he is incorrect'. ${ }^{107}$ While Greenwald said he did not want 'the prime minister's unbelievably reckless accusations' ${ }^{108}$ to distract from the

\footnotetext{
101 Johnson et al. 2014, p.796

102 Claire Trevett, Rebecca Quilliam and Derek Cheng, 'He's Dotcom's little henchman: PM attacks journalist's spy claims', The New Zealand Herald, 13 September 2014: http://www.nzherald.co.nz/nz/news/article.cfm?c_id=1\&objectid=11324113 (accessed 27 September 2014).

${ }^{103}$ Adam Bennett and Claire Trevett, 'Kiwis' data lodged with NSA - Greenwald', The New Zealand Herald, 15 September 2014:

http://www.nzherald.co.nz/nz/news/article.cfm?c_id=1\&objectid=11324685 (accessed 27 September 2014).

104 'Key: US journalist Greenwald 'a loser"” The New Zealand Herald, 15 September 2014: http://www.nzherald.co.nz/national/news/video.cfm?c id=1503075\&gal_cid=1503075\&gallery id=14 5457 (accessed 27 September 2014).

${ }_{105}$ John Key cited in Hume, 'Snowden, Assange, Greenwald, Dotcom: Can this gang of four take down a PM'.

106 Bennett and Trevett, 'Kiwis' data lodged with NSA - Greenwald'.

107 Trevett, Quilliam and Cheng, 'He's Dotcom's little henchman'.

${ }^{108}$ Greenwald, Transcript of 'The Moment of Truth'.
} 
substantive issues, he said he 'would not be paid a single penny' ${ }^{109}$ for his work in New Zealand. He also said the idea he had suddenly developed an 'urgent desire to manipulate the outcome of New Zealand's election is so frivolous that no one could really say it with a straight face'. ${ }^{110}$

At the same time, Mr Greenwald's arrival in New Zealand prompted Prime Minister Key to publicly acknowledge for the first time since the GCSB controversy had begun the existence of plans for a 'cable access surveillance programme'. ${ }^{111} \mathrm{Key}$ said the government had begun work on presenting a business case for the project, which he described as a 'mass cyber security protection initiative', ${ }^{112}$ but he personally stopped the work in March 2013 because he thought it was a step too far. Key claimed that the project was replaced by a narrower initiative, described as a more limited version of mass cyber protection, with tailored functionality which an individual company or agency could deploy. ${ }^{113}$ Anthony Briscoe, Chief Executive of Southern Cross Cables, also released a statement saying there was 'no facility by the NSA, the GCSB or anyone else on the Southern Cross cable network'. ${ }^{114}$

But Greenwald argued the Prime Minister was misleading the New Zealand public. The journalist maintained that documents provided by Edward Snowden would show that the GCSB has been involved in a mass surveillance programme code-named 'Speargun'. ${ }^{115}$ The Prime Minister repeated his claims stating that 'when it comes to New Zealanders, there is no mass surveillance'. ${ }^{116}$ Opposition leaders

\footnotetext{
${ }^{109}$ Ibid., p. 10 .

110 Ibid., p. 10

111 John Key cited in Hume, 'Snowden, Assange, Greenwald, Dotcom: Can this gang of four take down a PM'.

112 'Key: US journalist Greenwald 'a loser'”.

${ }^{113}$ Ryan Gallagher, 'The questions for New Zealand on mass surveillance', The Intercept, 16 September 2014, https://firstlook.org/theintercept/2014/09/15/questions-new-zealand-masssurveillance/ (accessed 27 September 2014).

${ }^{114}$ Anthony Briscoe cited in Hume, 'Snowden, Assange, Greenwald, Dotcom: Can this gang of four take down a PM'.

115 Trevett, 'He's Dotcom's little henchman'.

116 Trevett, "He's Dotcom's little henchman'.
} 
such as the then Labour Party Leader, David Cunliffe, and Green Party Co-Leaders, Metiria Turei and Russel Norman, were quite measured in their public responses to Greenwald's serious allegations. Both the Labour and Green parties pledged, if elected to government, to review the role of the GCSB, ${ }^{117}$ but also stated that they would not necessarily withdraw New Zealand from the Five Eyes arrangement if they formed a government. ${ }^{118}$ David Cunliffe maintained that 'New Zealand gains more than it contributes ${ }^{119}$ from the Five Eyes arrangement.

In an extraordinary attempt to refute Greenwald's claims of mass surveillance, Prime Minister Key indicated shortly before 'The Moment of Truth' event that he was prepared to declassify highly sensitive documents to prove that the GCSB pulled the plug on plans to spy on New Zealanders. ${ }^{120}$ However, the Prime Minister also stated that he would not the release the documents until after Greenwald tried to prove there was substance to his claims. ${ }^{121}$

Mass Surveillance in New Zealand: Claims and Denials

On 15 September, the day of 'The Moment of Truth' event, two articles were published on The Intercept. The first, written by Edward Snowden, unequivocally stated that New Zealanders were subject to mass surveillance. Snowden recalled that when he worked for the NSA he routinely came across communications of New Zealanders whilst working on 'XKEYSCORE', a surveillance tool the NSA shares

\footnotetext{
117 Botur, 'The GCSB does not conduct mass surveillance on Kiwis'.

118 Botur, 'The GCSB does not conduct mass surveillance on Kiwis'.

119 Botur, 'The GCSB does not conduct mass surveillance on Kiwis'.

${ }^{120}$ Claire Trevett, 'Spying claims force PM to release declassified documents', The New Zealand Herald, 14 September, 2014,

http://www.nzherald.co.nz/nz/news/article.cfm?c_id=1\&objectid=11324278 (accessed 27 September 2014).

${ }^{121}$ Derek Cheng, 'Spy case: No documents until claims verified - Key', The New Zealand Herald, 14 September 2014, http://www.nzherald.co.nz/nz/news/article.cfm?c_id=1\&objectid=11324494 (accessed 27 September 2014).
} 
with the GCSB. 'XKEYSCORE' allows total access to the database of communications collected in the course of mass surveillance and is used primarily for reading individual's private correspondence. ${ }^{122}$

Published alongside Snowden's article in The Intercept was an article by Glenn Greenwald. He claimed that the New Zealand government secretly worked to use the enhanced powers of the August 2013 GCSB Amendment Act, passed in the wake of illegal domestic spying revelations, in order to initiate a new metadata collection program that appeared to have been designed to collect information about the communications of New Zealanders. ${ }^{123}$ According to Greenwald, top secret documents obtained by Snowden showed that the GCSB, with on-going NSA cooperation, completed Phase I of a mass surveillance program, codenamed 'Speargun', at some point in early 2013. ${ }^{124}$ This involved the covert installation of 'cable access' equipment, which appeared to refer to surveillance of the Southern Cross cable, ${ }^{125}$ a trans-Pacific telecommunications network that connects New Zealand to the rest of the world. Speargun then moved to Phase II, under which 'metadata probes' were to be inserted into the Southern Cross cable, and that was scheduled for mid-2013. ${ }^{126} \mathrm{He}$ also provided evidence of NSA planning documents, which show that completion of Speargun was awaiting the new GCSB Amendment Act. $^{127}$

Greenwald's argument was apparently supported by the release of a document, in August 2014, which revealed an NSA engineer had visited New Zealand in February

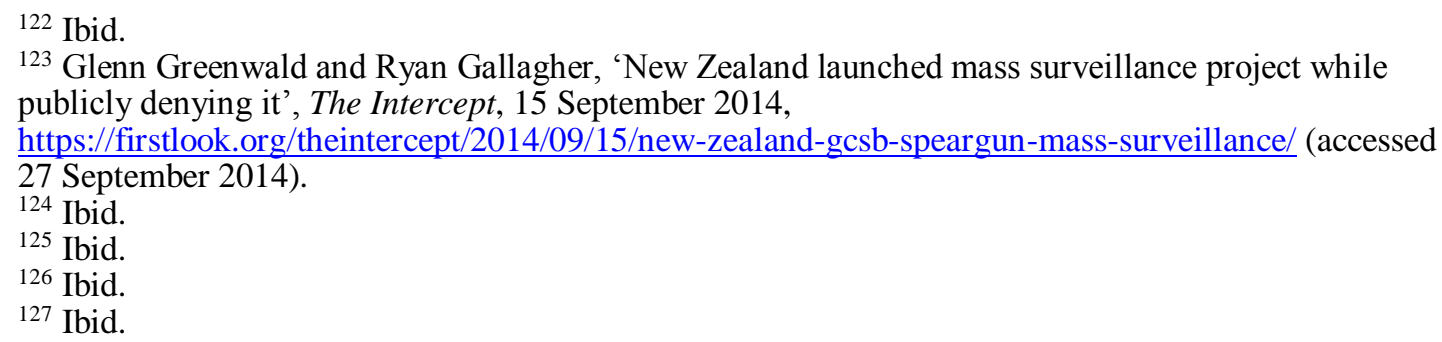


2013 to discuss with GCSB officials how to intercept electronic traffic on the Southern Cross cable. ${ }^{128}$ New Zealand lawyer, Denis Tegg, found a reference to the engineer's visit in NSA documents, stating that the engineer was in New Zealand for technical discussions regarding a future GCSB Special Source Operations (SSO) site. ${ }^{129}$ These SSO sites reportedly have the capacity to tap into countries' fibre optic cables so that phone calls, internet and email use can be intercepted and monitored. According to Edward Snowden, the SSO is a division of the NSA. An interception point on the Southern Cross cable would therefore mean that all of New Zealand's international communications could be accessed. It was further argued that such a major policy decision could only have been authorized by the Prime Minister, the Minister responsible for the NZSIS and GCSB. Notwithstanding these claims, John Key firmly denied that any such programme operated in New Zealand, or that there was any intention of introducing one. ${ }^{130}$ According to Green Party co-Leader, Dr Russel Norman, 'data collection on this scale would represent a massive expansion in the capabilities of the GCSB and shows just how close the relationship is between New Zealand and US spy agencies'.131

With the publication of the articles by Snowden and Greenwald, Prime Minister Key immediately declassified four documents, which he believed would confirm that the government had abandoned plans for a form of cyber protection, which could encroach on the privacy of New Zealand citizens. These documents were previously classified 'secret' presumably for reasons of national well-being. The Prime Minister said there was no public interest in making the information available during the

\footnotetext{
${ }^{128}$ Liz Banas, 'Govt call to account for spy claims', Radio New Zealand News, 1 August 2014, http://www.radionz.co.nz/news/national/251191/govt-called-to-account-for-spy-claims (10 October 2014).

129 Ibid.

${ }^{130}$ Ibid.

131 James Henderson, 'Key must “come clean" on NSA/GCSB fibre optic cable interception', Techday, 04 August 2014, http://telcoreview.co.nz/story/key-must-come-clean-on-nsa-gcsb-fibre-optic-cableinterception/ (accessed 27 September 2014).
} 
intense debate over the GCSB Amendment Bill in 2013. ${ }^{132}$ However, he seemed to think the allegations of mass surveillance in New Zealand by the likes of Edward Snowden and Glenn Greenwald had completely changed the situation. According to Key, Snowden and Greenwald 'are deliberately attempting to damage my reputation and tell New Zealanders that I'm doing something that I'm not and I've got no option but to protect myself'. ${ }^{133}$ Greenwald noted that Key 'was not releasing...classified information for any other reason than protecting his reputation and for political gain'. ${ }^{134}$ Certainly, Mr Key's rapid decision to declassify and release secret documentation had the potential to 'damage the security, defence, or international relations of New Zealand and/or friendly governments'. ${ }^{135}$ In the event, the released documents shed some light, but failed to decisively settle the question of whether New Zealanders were subject to mass surveillance.

The documents confirmed the existence of a cyber-protection project called Cortex which had the limited objective of protecting government agencies and key infrastructure providers from cyber-attack. ${ }^{136}$ In 2011, the Key government decided to build a cyber-defence system following a series of external cyber-attacks on New Zealand institutions, starting in 2009. A GCSB spokesperson subsequently sought to clarify the Cortex system by acknowledging that Speargun was a code that referred to

\footnotetext{
132 David Fisher, 'Secret dangers of released GCSB documents', The New Zealand Herald, 16 September 2014: http://www.nzherald.co.nz/nz/news/article.cfm?c_id=1\&objectid=11325743 (accessed 27 September 2014).

133 Ibid.

${ }^{134}$ Glen Greenwald cited in Toby Manhire, 'Greenwald, Dotcom, Snowden and Assange take on 'adolescent' John Key', The Guardian, 15 September 2014: http://www.theguardian.com/world/2014/sep/15/moment-truth-greenwald-dotcom-snowden-assangenew-zealand-john-key (accessed 27 September 2014).

${ }^{136}$ Fisher, 'Secret dangers of released GCSB documents'.
} 
an early core component of the cyber defence project that was later jettisoned by Prime Minister Key. ${ }^{137}$

But Snowden and Greenwald responded by saying that the Key government and GCSB were deliberately conflating cyber protection with a mass surveillance capability. The four de-classified documents made no mention of the SPEARGUN capability, so it was unclear whether the abandoned element of CORTEX system was called SPEARGUN. At 'The Moment of Truth' event, Snowden stated 'there are actually NSA facilities in New Zealand that the GCSB is aware of, and that means the Prime Minister is aware of, and one of them is in Auckland'. ${ }^{138}$ According to Snowden, Prime Minister Key's refusal to comment on XKEYSCORE was telling: 'What about the GCSB's involvement in XKEYSCORE? What about New Zealand's involvement in the XKEYSCORE mass surveillance program?' ${ }^{139}$ Key claimed he could not comment as XKEYSCORE is related to foreign intelligence. 'But is it related to foreign intelligence', Snowden argued, 'if it's collecting the communications of every man, woman and child in the country of New Zealand? ${ }^{140}$ Thus, Snowden claims that Key's government's denials about mass surveillance in New Zealand 'is a careful parsing of words'. ${ }^{141}$ As a member of Five Eyes intelligence sharing arrangement, Snowden maintains that the GCSB is cooperating closely with its senior partner NSA, and therefore the 'NSA is doing it [mass surveillance] and then providing that same information to us [GCSB], so we don't have to do it domestically'. ${ }^{142}$

\footnotetext{
${ }^{137}$ Tom Pullar-Strecker, 'GCSB clarifies 'Project Speargun'”, The New Zealand Herald, 19 September 2014, http://www.stuff.co.nz/technology/digital-living/61372504/gcsb-clarifies-project-speargun (accessed 27 September 2014).

138 Edward Snowden, Transcript of 'The Moment of Truth'.

139 Ibid., p. 21.

140 Ibid., p. 19.

141 Ibid., p. 19.

142 Ibid., p. 20.
} 
Prime Minister John Key has denied that the NSA is operating in New Zealand, but he continued his refusal to comment on XKEYSCORE. ${ }^{143}$ However, a former Director of the GCSB, Bruce Ferguson, admitted its agents were trained in the use of data-harvesting technology. ${ }^{144}$ Mr Key’s office also declined to explain the process for making the CORTEX project documents available to the public, but said the Prime Minister was not concerned about any dangers arising from their declassification.

\section{Political Parameters of the Surveillance Controversy}

Despite the 'Moment of Truth' revelations, the Prime Minister's reading of the public response to the surveillance debate, in the short term at least, proved to be astute. John Key apparently believed that an uncompromising approach to the complex surveillance question - given the strength of the economic record of his government and the absence of strong or political opposition from the Labour and Green parties on the surveillance issue - would persuade most New Zealanders to give his National-led government the benefit of the doubt. His political judgment seemed vindicated. On 20 September 2014, Mr Key's National Party won a third term with 47 per cent of the party vote. ${ }^{145}$ That gave it 60 seats in the 121 member Parliament and allowed the National Party to form a government under its leadership for a third successive term.

Immediately after its re-election, the Key government emphasized that the terrorist threat presented to New Zealand by ISIS was very real and a number of New

143 Andrea Vance, 'NZ spied on allies, Greenwald claims', The New Zealand Herald, 17 September 2014 , http://www.stuff.co.nz/national/politics/10505138/NZ-spied-on-allies-Greenwald-claims (accessed 27 September 2014).

${ }^{144}$ Ibid.

${ }^{145}$ Isaac Davidson, 'Final election result in: National loses majority', The New Zealand Herald, 5 October 2014, http://www.nzherald.co.nz/nz/news/article.cfm?c_id=1\&objectid=11337042 (accessed 10 October 2014). 
Zealand citizens were either fighting for ISIS in Syria or were actively supporting this organization from New Zealand. The Key government also signalled that it expected an invitation to join the anti-ISIS coalition in the near future. ${ }^{146}$ In the meantime, the Prime Minister signalled his intention to make a major speech on national security and to take a more robust stance on security and intelligence issues, despite the controversies involving the GCSB and the Snowden revelations during his second term. $^{147}$

On balance, the GCSB Amendment Bill and the Snowden revelations did inspire some institutional changes in the political system. Kim Dotcom's creation of the Internet Party was a direct response to claims of mass surveillance in New Zealand. The 'Moment of Truth', arranged by Dotcom with Snowden in attendance, was timed to have a significant impact on voter behaviour. However, other New Zealand opposition parties were much less willing to focus on the surveillance controversy, and ultimately the 'Moment of Truth' failed to have much immediate effect on New Zealand voters. Indeed, the Internet Party experienced a humiliating electoral result and disbanded in the aftermath of the 2014 election. At the same time, an energetic and lively debate on surveillance policy at the agendas level did not translate into major political changes at the institutions level. John Key's National Party was elected for a third term, and the Key leadership wasted little time in announcing a major overhaul of the security and intelligence sector to face what it termed future terrorist threats facing New Zealand and the region.

\footnotetext{
${ }^{146}$ Reissa Su, 'New Zealand PM John Key Expects Invitation to Join Fight Against ISIS', International Business Times, 7 October 2014, http://au.ibtimes.com/articles/568744/20141007/new-zealand-johnkey-isis-terrorism.htm\#.VFqdDYfTKPz (accessed 10 October 2014).

${ }^{147} \mathrm{Su}$, 'New Zealand PM John Key Expects Invitation to Join Fight Against ISIS'.
} 


\section{Impact of the Surveillance Controversy at the Policy Level}

According to Williams' conceptualization of public impact, the implementation of legislative changes offers clear indicators of the influence of developments on the policy level. In New Zealand, the GCSB Amendment Act was narrowly passed in August 2013, despite the beginning of the Snowden leaks. Nevertheless, there is evidence that the prolonged and intense national debate and exchanges on surveillance in 2013-14 at the agendas and institutions levels contributed to government measures relating to enhanced accountability and oversight of New Zealand's intelligence community.

Bolstering Oversight of New Zealand's Intelligence Agencies

In April 2014, Prime Minister Key announced the appointment of lawyer Cheryl Gwyn as the new Inspector-General of Intelligence and Security (IGIS). ${ }^{148}$ Ms Gwyn took up her appointment on 5 May and succeeded the outgoing Inspector-General, the Honourable R. Andrew McGechan QC. In July 2014, the New Zealand government appointed the first ever Deputy Inspector-General of Intelligence and Security, $\mathrm{Mr}$ Ben Keith. ${ }^{149}$ This appointment was part of the process of strengthening the oversight capabilities of the Inspector-General's office following amendments to the InspectorGeneral of Intelligence and Security Act 1996 in September 2013. Under these

\footnotetext{
${ }^{148}$ New Zealand Intelligence Community, 'New Inspector-General of Intelligence and Security Appointed', 23 April 2014, http://nzic.govt.nz/resources/ (accessed 10 October 2014).

${ }_{149}$ New Zealand Government Press Release, 'Deputy Inspector-General Intelligence named', Scoop Independent News, 2 July 2014, http://www.scoop.co.nz/stories/PA1407/S00050/deputy-inspectorgeneral-intelligence-named.htm (accessed 10 October 2014).
} 
amendments, the Inspector-General would be supported by a newly created Advisory Panel consisting of three members, one of whom would be Ms Gwyn. ${ }^{150}$

The strengthening of the IGIS's oversight team coincided with a critical performance review of the New Zealand Intelligence Community (NZIC) published by the State Services Commission in early July 2014. The report found that the national security and intelligence priorities were inadequately defined and that basic systems were weak and required attention. ${ }^{151}$ The report also confirmed that, following Snowden's revelations, it was difficult to determine exactly how much faith the public had in New Zealand intelligence agencies. ${ }^{152}$ The report said NZIC objectives should include attempts to work together effectively, act within legal compliance and improve its public mandate. ${ }^{153}$ The latter observation may have been linked to a poll taken in June 2014, which showed that 71.6 per cent of New Zealanders believed that United States spy agencies are gathering data on them. ${ }^{154}$

Snowden indicated that the NSA had advised the GCSB to find or create loopholes in New Zealand law to enable widespread spying. ${ }^{155}$ In testimony to the European Parliament, Snowden revealed that the NSA puts pressure on other countries to change laws to create legal gaps through which mass surveillance could be carried out. ${ }^{156}$ At the same time, Snowden's leaks pinpointed some of the targets of Five Eyes' signals intelligence collection efforts. These included the private telephones of German Chancellor Angela Merkel and Indonesian Prime Minister

\footnotetext{
${ }^{150}$ Inspector-General of Intelligence and Security Media Release, 'Advisory Panel members appointed', 23 October 2014, http://www.igis.govt.nz/announcements/ (accessed 25 October 2014).

${ }^{151}$ Peter Bushnell and Garry Wilson, 'Performance Improvement Framework: Review of the agencies in the core New Zealand Intelligence Community (NZIC)', Unclassified Summary, July 2014, http://www.ssc.govt.nz/sites/all/files/PIF-Review-NZIC-Jul14.pdf (accessed 27 September 2014) p.6. 152 Ibid., p.9.

${ }^{153}$ Ibid., pp.6-7.

${ }^{154}$ Tegg, 'Is warrant-less spying on New Zealanders lawful?'

155 'Snowden says US aids NZ spying', Otago Daily Times, 11 March 2014, http://www.odt.co.nz/news/politics/294730/snowden-says-us-aids-nz-spying (accessed 27 September 2014).

156 Ibid.
} 
Susilo Bambang Yudhoyono, the email systems of the Brazilian Ministry of Energy and Mining, Mexican politicians, Arab dictators, Malaysian government agencies and Chinese telecommunication firms. ${ }^{157}$ Such revelations led to strong diplomatic protests, most notably from German Chancellor Angela Merkel, who said 'spying amongst friends' was 'unacceptable' and compared the NSA with the Stasi. ${ }^{158}$

In February 2014, the European Parliaments Committee on Civil Liberties, Justice and Home Affairs condemned New Zealand for its involvement in mass surveillance as part of the Five Eyes alliance. ${ }^{159}$ The Committee found that New Zealand had been involved on a large scale in mass surveillance of electronic communications, had actively cooperated with the US and may have exchanged with other members personal data of European Union (EU) citizens transferred from the EU. ${ }^{160}$ The Committee's finding was that, because of the GCSB's integration into the NSA spying network, the EU does not trust New Zealand laws. ${ }^{161}$ In New Zealand, the fallout from the Snowden revelations focused the attention of the New Zealand public on the role of the GCSB, the GCSB's relationship with the NSA and the impact this has had on New Zealand's political autonomy. ${ }^{162}$

Thus, the surveillance controversy had some impact at the policy level prior to the general election of September 2014. The GCSB Amendment Bill was passed in the face of considerable domestic opposition, but this opposition - now buoyed by the continuing Snowden revelations - may well have been a factor in the Prime Minister's

\footnotetext{
${ }^{157}$ Paul Buchanan, 'Snowden Leaks sure to catch NZ out', The New Zealand Herald, 3 December 2013, http://www.nzherald.co.nz/world/news/article.cfm?c id=2\&objectid=11165857 (accessed 14 October 2014).

${ }^{158}$ Luke Baker and Andreas Rinke, 'Merkel frosty on the U.S. over 'unacceptable' spying allegations', Reuters, 24 October 2013, http://www.reuters.com/article/2013/10/24/us-eu-summitidUSBRE99N0BJ20131024 (accessed 14 October 2014); Ian Traynor and Paul Lewis, 'Merkel compared NSA to Stasi in heated encounter with Obama', The Guardian, 17 December 2013. http://www.theguardian.com/world/2013/dec/17/merkel-compares-nsa-stasi-obama (accessed 14 October 2014).

${ }^{159}$ Crowe, 'EU Parliament slams New Zealand for being part of NSA mass surveillance'.

${ }^{160}$ Ibid.

${ }^{161}$ Ibid.

162 Burton, 'Small States and Cyber Security: The Case of New Zealand', p.234.
} 
decision to enhance oversight and attempt to boost public confidence in an intelligence service damaged by two consecutive scandals.

The Post-Election Revamp of Security and Intelligence

On 6 October 2014, Mr Key announced a major overhaul of the security and intelligence sector. Under the new arrangements, the Prime Minister took on the new role of Minister for National Security and Intelligence and would retain strategic leadership in this sector as a whole. At the same time, the Attorney-General, Mr Chris Finlayson became the Minister in Charge of the NZ Security Intelligence Service and Minister Responsible for the GCSB, and assumed responsibility for the day-to-day running of these agencies within the policy framework set by the Prime Minister. In addition, Mr Key indicated he would establish and chair a new National Security Committee of Cabinet. ${ }^{163}$ These changes, according to the Prime Minister, 'will make our structure very similar to that seen in Australia and Great Britain' and would help New Zealand deal with 'threats in the ever-changing environment'. ${ }^{164}$

Within days, the New Zealand government spelled out the sort of threat the country was now facing. In the wake of raids by Australian police targeting alleged Islamic State terrorists in Sydney and Brisbane, Mr Key said a 'domestic beheading' inspired by ISIS extremists could not be ruled out in New Zealand. ${ }^{165}$ As an upshot, the New Zealand government raised the country's national threat level from very low

\footnotetext{
${ }^{163}$ New Zealand Government Media Statement, 'National Security and Intelligence role created', Scoop Independent News, 6 October 2014, http://www.scoop.co.nz/stories/PA1410/S00026/nationalsecurity-and-intelligence-role-created.htm (15 October 2014); Adam Bennett, 'John Key unveils new Cabinet line-up', The New Zealand Herald, 05 October 2014,

http://www.nzherald.co.nz/nz/news/article.cfm?c_id=1\&objectid=11337743 (15 October 2014).

${ }_{164}$ New Zealand Government, 'National Security and Intelligence role created'.

165 'Isis fight: NZ might join combat operations', The New Zealand Herald, 11 October 2014, http://www.nzherald.co.nz/nz/news/article.cfm?c_id=1\&objectid=11340983 (accessed 15 October 2014).
} 
to low. While previously the threat of a terrorist attack was deemed unlikely, it was now assessed as possible but not expected. ${ }^{166}$

Mr Key's keenly anticipated speech on New Zealand's national security was delivered on 5 November 2014. He said 'the rise of a well-resourced, globallyfocused terrorist entity' like ISIS, which is 'highly skilled in recruitment techniques utilizing social media', was 'a game changer for New Zealand'. ${ }^{167} \mathrm{He}$ identified between 30 and 40 New Zealanders who are actively engaged in advancing the ISIS cause, whether in Syria, Iraq or New Zealand. The Prime Minister also said a further 30 to 40 people potentially had terrorist links and required further investigation. In short, New Zealand no longer has 'a benign threat environment'. ${ }^{168}$ But while the government would not send combat troops to directly fight ISIS, it will send ten military planners to explore the possibility of providing military training assistance to Iraqi forces, and boosted New Zealand's humanitarian aid for Syrian and Iraqi refugees. Furthermore, Key announced several domestic measures aimed at boosting security. These included increasing the length of time the government could cancel a passport on national security grounds from one to three years; new government powers to temporarily suspend passports; broader NZSIS surveillance powers such as extending video monitoring of private property for security related activities and conducting warrantless surveillance for up to 48 hours; and increasing the funding of the NZSIS by almost NZ\$7 million. ${ }^{169}$

But a number of observers seriously questioned the appropriateness of expanding the surveillance powers of New Zealand's intelligence agencies to counter the ISIS

\footnotetext{
166 'NZ terrorism threat level raised', Radio New Zealand, 13 October 2013, http://www.radionz.co.nz/news/political/256735/nz-terrorism-threat-level-raised (accessed 15 October 2014).

${ }^{167}$ New Zealand Government, 'John Key Speech to NZ Institute of International Affairs', 05 November 2014, http://www.beehive.govt.nz/speech/speech-nz-institute-international-affairs-0 (accessed 01 December 2014). 168 Ibid.

169 Ibid.
} 
terrorist challenge. For one thing, the scale of the threat was disputed. Javed Khan, Vice-President of the New Zealand Federation of Islamic Associations, was surprised and alarmed by the threat outlined by John Key. He said he was aware of five to ten people associated with Islamic State, but not the 80 or so mentioned by the Prime Minister. ${ }^{170}$ Dr Paul Buchanan, a Security Consultant, said the Government would have to be careful about correctly identifying people leaving New Zealand to fight with Islamic State: 'For example, there are members of the Syrian community who for family and personal reasons have chosen to go back and may well be fighting for the Free Syrian Army which of course is backed by the West in the fight against [Syrian President] Assad'. ${ }^{171}$ Human rights lawyer Michael Bott broadly agreed and argued the Key government's new domestic security measures were disproportionate to the actual threat level to New Zealand and would erode personal freedoms: 'If these people are to be monitored now then why do we have to...give the state more power to intrude on our lives. The changes have to be proportionate and at this stage we haven't seen the evidence'. ${ }^{172}$ Similarly, Dr Nigel Parsons, a Middle East specialist at Massey University, said it was easy to overstate the risks being posed to New Zealand by ISIS: 'Once civil liberties are gone, once powers of surveillance are increased, those powers are typically difficult to roll back and those liberties are difficult to reclaim'. ${ }^{173}$

In the aforementioned speech by John Key on New Zealand's national security policy, the Prime Minister said international consultations, 'including with our Five

\footnotetext{
170 'Fears over IS law changes dismissed', Radio New Zealand News, 06 November 2014, http://www.radionz.co.nz/news/national/258672/fears-over-is-law-changes-dismissed (accessed 01 December 2014).

171 'Govt developing policy on fighters', Radio New Zealand News, 07 November 2014, http://www.radionz.co.nz/news/political/258793/govt-developing-policy-on-fighters (accessed 01 December 2014).

172 'Fears over IS law changes dismissed'.

173 Ibid.
} 
Eyes partners...provided a base for our decision-making'. ${ }^{174}$ Convinced that partnership with Five Eyes 'has provided New Zealand with global information on international security and intelligence issues that we could never have achieved on our own', Mr Key maintained 'Five Eyes does not cost us our independence' and 'will be an important part of how we deal with the threat of ISIL at home and abroad'. ${ }^{175}$ But have the political costs of New Zealand participation in the Five Eyes alliance risen since the GCSB Amendment bill controversy and the Snowden revelations implicating the GCSB in NSA-led mass surveillance? The answer will depend on how the actions of the New Zealand government are viewed over time in a fast globalizing world.

\section{Evaluating the Public Impact of the GCSB Amendment Bill and the Snowden}

\section{Revelations in New Zealand}

Until the recent surveillance controversies, New Zealand has been able, so to speak, to fly under the radar and was widely seen as relatively benign in intelligence terms. This was probably due to an awareness of the ANZUS split in the mid-1980s and New Zealand's occasional willingness to oppose US foreign policy initiatives, such as the US-led invasion of Iraq in March 2003. But a combination of the GCSB Amendment Bill and Snowden's leaked documents changed this situation. Above all, these developments made it clear that the intelligence relationship between New Zealand and the US (as well as those with the UK, Australia and Canada) has been much closer than generally realized.

174 New Zealand Government, 'John Key Speech to NZ Institute of International Affairs'.
${ }^{175}$ Ibid. 
Yet, in the short term at least, the political and diplomatic costs of the intelligence controversies do not appear to be have been significant for the Key government. By focusing on three different levels of public impact - agendas, institutions and policy - we have shown that an intense national debate on surveillance did not readily translate into major changes in the direction of government policy. Mr Kim Dotcom and the leader of the then Internet Party, Ms Laila Harré, anticipated that the 'Moment of Truth' event scheduled on the eve of the New Zealand general election, featuring the likes of Glenn Greenwald, Edward Snowden and Julian Assange, would crystallize domestic political concerns and counter the Key government's claim, in its campaign for a Security Council seat, that New Zealand pursued an independent foreign policy. ${ }^{176}$ However, these expectations were not realized. As related, on 20 September 2014, the Key government was decisively re-elected for a third term. Moreover, on 16 October 2014, John Key's New Zealand, competing with two much larger countries - Spain and Turkey - for two seats on the Security Council, resoundingly won a seat in the first ballot in New York. $^{177}$

So why did the lively debate on surveillance within New Zealand society fail to have an immediate impact at the policy level? After all, a poll conducted in early 2015 by Amnesty International which surveyed 15,000 people in 13 countries around the world, including New Zealand, confirmed that New Zealand was amongst a cluster of countries that expressed clear opposition to domestic mass surveillance and the

\footnotetext{
176 Jim McLay, New Zealand ambassador to UN, quoted in 'Security Council seat won't harm NZ foreign policy', One News TVNZ, 19 October 2014, http://tvnz.co.nz/national-news/security-councilseat-won-t-harm-nz-foreign-policy-un-ambassador-6111094 (accessed 26 October 2014).

177 Vaughan Elder, 'Stunning outcome for NZ', Otago Daily Times, 18 October 2014, http://www.odt.co.nz/news/national/320317/stunning-outcome-nz (accessed 21 October 2014).
} 
involvement of their governments in spying on other countries. ${ }^{178}$ Several factors seem to account for the apparent discrepancy. First, according to Rebecca Emery, the New Zealand public probably felt 'quite powerless' ${ }^{\text {'179 }}$ in relation to a complex issue like surveillance. Blanket denials by the Key government and the unwillingness of David Cunliffe's Labour party - the major opposition group in Parliament - to clearly challenge Key's narrative meant that many New Zealanders tended to give the Prime Minister the benefit of the doubt on this issue and focused on 'bread and butter' election issues. Second, and not unrelated, the mass surveillance controversy only emerged in earnest in New Zealand in 2013 and the running on this new issue was largely made by relatively small political parties like the Greens or the Internet party and individuals like the German born entrepreneur Kim Dotcom, foreign journalists like Glenn Greenwald, and foreign whistleblowers such as Edward Snowden. In the circumstances, Prime Minister Key played the patriotic card by strongly implying that these foreign-born critics were deliberately acting against New Zealand's national interests and that he had to strengthen the national security sector to keep the country safe from Islamist terror.

However, the impact of the surveillance debate at the policy level could yet prove to be very significant for New Zealand in the long-term. The intimacy and accessibility of the country's political system means that public opinion still remains potentially a potent factor in the shaping of policy. To date, the Key government has been able to maintain its domestic support in the face of the controversies generated by the GCSB Amendment Bill and the Snowden leaks. But such support cannot be regarded as a permanently operating factor. As noted, the Key government has sought

\footnotetext{
178 Rebecca Emery, 'Rebecca Emery, Amnesty International's 'Unfollow Me Campaign', interviewed by Wallace Chapman, Sunday Morning programme, New Zealand National Radio, 29 March 2015, http://www.radionz.co.nz/national/programmes/sunday/20150329 (accessed 30 March 2015). ${ }^{179}$ Ibid.
} 
to ameliorate public concerns over intelligence operations by strengthening the oversight capabilities of the Inspector-General's office. While this measure does not eliminate the problem of the Prime Minister appointing both the Directors of the GCSB and SIS and the Inspector-General of Security and Intelligence, it has already begun to have consequences for the conduct of national security policy. In late November 2014, an inquiry headed by the Inspector-General of Security and Intelligence, Cheryl Gwyn, found that the NZSIS released incomplete and misleading classified information in response to an Official Information Act request by blogger Cameron Slater. ${ }^{180} \mathrm{Mr}$ Slater was encouraged to make this request by members of the Prime Minister's staff and he used the information obtained to politically undermine Mr Goff's claim that he had not been briefed by the NZSIS on Israeli intelligence activities in Christchurch in 2011. The Director of the NZSIS was instructed by Ms Gwyn to provide an unreserved apology to the former Labour leader. ${ }^{181}$

At the same time, there remains a wide gulf between Prime Minister Key's firm denial that New Zealand is involved in mass surveillance and continuing revelations from Edward Snowden that strongly implicate New Zealand's intelligence agencies in such activity. While international opinion remains sharply divided over Snowden's actions, there is little or no evidence to show that his claims about the NSA and its surveillance work through the Five Eyes alliance are inaccurate. In October 2014, documents released by Snowden seemed to show the NSA and partners like the GCSB have been involved in intelligence gathering activities in friendly countries whether in the Pacific, Europe or Asia. ${ }^{182}$ In early March 2015, investigative

\footnotetext{
${ }^{180}$ Vernon Small and Stacey Kirk, 'Dirty Politics' Report Directs Harsh Criticism at SIS', Stuff News, 25 November 2014, http://www.stuff.co.nz/national/politics/63505210/Dirty-politics-report-directsharsh-criticism-at-SIS (01 December 2014).

181 Ibid.

182 Andrea Vance, 'NZ embassies used by spies:docs', The New Zealand Herald, 13 October 2014. http://www.stuff.co.nz/national/politics/10610620/NZ-embassies-used-by-spies-docs (12 November 2014).
} 
journalist Nicky Hager and Ryan Gallagher, a reporter for The Intercept, published claims, derived from leaked Snowden files, that the GCSB has dramatically expanded its spying operations during the John Key government at the behest of the NSA.

The documents provided by Snowden showed that the GCSB base at Waihopai has moved to 'full-take collection' (which means that the base now collects and retains everything it intercepts), with much of its attention directed 'against a surprising array of New Zealand's friends, trading partners and close Pacific neighbours. These countries' communications are supplied directly to the NSA and other Five Eyes agencies with little New Zealand oversight or decision-making, as a contribution to US worldwide surveillance'. ${ }^{183}$ These targets include Pacific neighbours, such as Samoa, Vanuatu and Fiji. According to Hager and Gallagher, the Snowden documents indicated that counter-terrorism is at most a minor part of the GCSB's operations. ${ }^{184}$ Moreover, the Snowden documents contained information that New Zealand and America intelligence operatives were engaged in electronic spying on government buildings in Auckland belonging to Wellington's largest trade partner, China. ${ }^{185}$ It was also reported that Snowden's leaked information appeared to show that GCSB was used to spy on rivals to New Zealand Trade Minister, Tim Groser, for the position of Secretary General of the World Trade Organization (WTO) in 2013. ${ }^{186}$

These revelations had some immediate reverberations. New Labour leader Andrew Little said he was shocked to hear about mass spying in the Pacific while Green Party co-leader, Russel Norman, claimed the GCSB had broken the law by

\footnotetext{
183 Ibid.

184 Ibid.

185 David Fisher, 'Leaked papers reveal NZ plan to spy on China for US', The New Zealand Herald, 19 April 2015, http://www.nzherald.co.nz/nz/news/article.cfm?c_id=1\&objectid=11434886 (05 May 2015).

186 Tova O’Brien, 'GCSB claims detract from South Korea free trade deal', 3 News, 23 March 2015, http://www.3news.co.nz/nznews/gcsb-claims-overshadow-south-korean-free-trade-deal-2015032322 (05 May 2015).
} 
spying on New Zealand citizens in Pacific nations. ${ }^{187}$ On 26 March, following a formal complaint by the Green Party, it was reported that the Inspector-General of Intelligence and Security, Ms Cheryl Gwyn, would investigate whether the GCSB had illegally spied on New Zealanders working or travelling in the South Pacific. ${ }^{188}$ Meanwhile, reports that New Zealand had been spying on China sparked a firm diplomatic response. The Chinese Embassy in Wellington issued a statement, saying the Beijing was concerned about such reports and that it would 'firmly safeguard our security interests'. ${ }^{189}$ In addition, the Brazilian government reacted angrily to reports that the GCSB had spied on its successful campaign to get diplomat Roberto Azevedo elected as Secretary General of the World Trade Organization. It demanded an explanation from the Key government and summoned New Zealand's ambassador in Sao Paulo, Caroline Bilkey, to Brazil's Foreign Ministry headquarters to provide one. $^{190}$

Such developments point to the very real prospect of a credibility gap in the national security policy of New Zealand. If the Key leadership continues to contribute to a massively increased NSA-led Five Eyes covert surveillance effort, it runs the risk of undermining the political and diplomatic legitimacy of the country. New Zealand has branded itself internationally as a small, democratic, Pacific state that has a diverse and independent foreign policy. But the GCSB Amendment Act and the Snowden revelations have undermined such claims. The Key government has

${ }^{187}$ David Fisher, 'Snowden GCSB Revelations/Russel Norman says GCSB 'breaking the law', The New Zealand Herald, 05 March 2015,

http://www.nzherald.co.nz/nz/news/article.cfm?c_id=1\&objectid=11411730 (05 May 2015).

${ }^{188}$ Russel Norman, 'GCSB Activity to be Investigated', interviewed by Mary Wilson, Radio New Zealand, 26 March 2015, http://www.radionz.co.nz/national/programmes/checkpoint/20150326 (accessed 28 March 2015).

${ }^{189}$ Fergus Ryan, 'China concerned at reports of NZ-US Plan to Spy on Diplomats', The Australian Business Review, 20 April 2015, http://www.theaustralian.com.au/business/latest/china-concerned-atreports-of-nz-us-plan-to-on-diplomats/story-e6frg90f-1227311899294 (accessed 01 May 2015). ${ }_{190}$ Audrey Young, 'GCSB spying reports: Brazil demands an explanation from New Zealand', The New Zealand Herald, 27 March 2015, http://www.nzherald.co.nz/nz/news/article.cfm?c id=1\&objectid=11424168 (accessed 01 May 2015). 
substantially expanded the surveillance powers of its intelligence agencies at a time when it acknowledges the Islamist terrorist threat to New Zealand is "low". Moves towards mass surveillance by the Five Eyes alliance members has increased the scope for the abuse of political power in Wellington, encroached on the privacy of lawabiding New Zealand citizens, potentially diminished the country's capacity to target real terrorist suspects, and clouds New Zealand's standing and relations with democratic allies in Pacific and South America and important trade partners like China. In short, there is a growing tension between the distinctive foreign policy aims and interests of New Zealand globally and its participation in a system of ubiquitous spying driven by the NSA within the Five Eyes Alliance.

It would be naïve to believe that the Key government is unaware of these risks. But it probably believes they are manageable, and that the benefits of Five Eyes membership are more than offset by the enhanced surveillance demands that the NSA has made upon fellow 'club' members since 2009. According to Joe Nye (Jr), '[i]nformation is the new coin of the international realm, and the United States is better positioned than any other country to multiply the potency of its hard and soft power through information'. ${ }^{191}$ Thus, the utilization of new technologies by the NSA for building a massively expanded surveillance system within Five Eyes is almost certainly linked to the geo-political goal of American primacy. However, while American power may explain the Key government's co-operative stance toward the Five Eyes surveillance agenda, there are several developments, singularly or collectively, that could de-stabilize Key's balance of advantage assessment at the policy level.

${ }^{191}$ Richard Falk, 'State of Siege: Will Globalisation Win Out?' International Affairs, 73/1 (January 1997) p.128. 
First, the cumulative impact of Snowden's continuing release of NSA documents will help keep the surveillance issue alive in New Zealand, and will only increase the chances of mainstream political contestation. Second, there is some evidence of pushback in the US to NSA activities. In May 2015, the US Court of Appeals, in a landmark decision, ruled that the bulk collection of telephone metadata by the NSA is unlawful. This could pave the way for a full legal challenge against the NSA, ${ }^{192}$ and that would certainly complicate New Zealand's participation in NSA-led surveillance programs. Third, New Zealand has no real hard power of its own to achieve its global interests. Instead, it relies heavily on soft power and trust to support them, and is therefore particularly vulnerable to retaliatory measures ${ }^{193}$ from states like Brazil and China that could be aggrieved by New Zealand's participation in Five Eyes spying operations. As a current member of the UN Security Council, with growing economic interests in the Asia-Pacific region, New Zealand cannot afford to be indifferent to growing concerns about its espionage role. The Key government will face growing domestic and international pressures to adjust its national security policy so that it is consistent with what is claimed to be an independent and diverse foreign policy. In short, it is certainly possible that New Zealand policy-making will be significantly affected by the unfolding controversy over surveillance in the reasonably near future.

\footnotetext{
192 Dan Roberts and Spencer Ackerman, 'NSA mass phone surveillance revealed by Edward Snowden ruled illegal', The Guardian, 07 May 2015, http://www.theguardian.com/us-news/2015/may/07/nsaphone-records-program-illegal-court (accessed 08 May 2015).

${ }_{193}$ Paul Buchanan, 'The Ethics of Spying on your Friends and Neighbours', interviewed by Wallace Chapman, Sunday Morning Programme, New Zealand National Radio, 29 March 2015,

http://www.radionz.co.nz/national/programmes/sunday/20150329 (accessed 30 March 2015).
} 